\title{
Redesain Meja dan Kursi Siswa di Yaketunis Yogyakarta
}

\author{
Wahyu Waskito Putra \\ Program Pascasarjana Institut Seni Indonesia Yogyakarta \\ wahyuwaskito31@gmail.com
}

\begin{abstract}
Abstrak
Meja dan kursi adalah fasilitas sekolah yang berpengaruh terhadap postur tubuh anak termasuk siswa tunanetra. Postur tubuh akan bekerja secara alami jika menggunakan meja dan kursi yang ergonomis. Sebaliknya, meja dan kursi yang tidak ergonomis cenderung menyebabkan keluhan muskuloskeletal. Penelitian pendahuluan dilakukan terhadap siswa tunanetra di Yaketunis dengan menggunakan metode design thinking dan dilanjutkan dengan checklist penelitian dan Standard Nordict Questionnaire (SNQ). Hasil checklist penelitian siswa kelas satu dengan rata-rata tinggi badan 115,6 $\mathrm{cm}$ diperoleh bahwa ketidaksesuaian dari tinggi meja dan tinggi kursi dengan siswa. Siswa kelas lima dengan rata-rata tinggi badan $133,7 \mathrm{~cm}$ diperoleh bahwa ketidaksesuaian tinggi meja dan tinggi kursi dengan siswa. Hal ini cenderung menyebabkan siswa mengalami keluhan muskuloskeletal yang diukur dengan SNQ pada leher, tangan, kaki, punggung, pinggang, siku, dan lutut. Meja dan kursi yang tidak ergonomis menyebabkan postur tubuh anak bekerja secara tidak alami. Ketidaksesuaian meja dan kursi dengan siswa diminimalisasi dengan redesain meja dan kursi berdasarkan antropometri tubuh siswa dengan metode perancangan Pahl dan Beitz. Metode ini terdiri dari perencanaan dan penjelasan tugas, perancangan konsep produk, perancangan bentuk produk dan perancangan detail. Redesain meja dan kursi anak ini menghasilkan bentuk yang sesuai dengan kebutuhan tubuh anak tunanetra dan keergonomiannya terhadap pengguna produk tersebut.
\end{abstract}

Kata kunci: tunanetra, keluhan muskuloskeletal, redesain, postur, antropometri, meja dan kursi

\begin{abstract}
Desk and chair are kinds of school furniture that influence for posture. Usage of unergonomically desk and chair will cause musculoskeletal complaint in student. Based on preliminary research conduct to student of ABC elementary school grade one and grade five with checklist and Standard Nordict Questionnaire (SNQ). Result of checklist in student grade one in average stature 115,6 cm mismatch hight of desk and hight of chair with the student. Student grade five in average stature 133,7 cm mismacth hight of desk and hight of chair with the student. This cause student musculoskeletal complaints result with SNQ in neck, hand, foot, back, wait, elbow and knee. Unergonomic desk and chair cause bad posture. Mismatch of desk and chair minimalizeted by redesign desk and chair with antropometry of student according to Pahl and Beitz methods. Step of this methods are clarification of task, conseptual design, embodiment design dan detail design. Redesign of school desk and chair result adjustable hight of desk and hight of chair with hight of desk 41,4-58,9 cm and hight of chair 30,2-40,6 cm. Width of desk $56,3 \mathrm{~cm}$, width of chair $27,3 \mathrm{~cm}$, lenght of chair $39,2 \mathrm{~cm}$ and height of backrest 43,5 cm.
\end{abstract}

Keywords: musculoskeletal disorders, redesign, posture, antropometry, desk and chair. 


\section{Pendahuluan}

Kemampuan penglihatan sangat berpengaruh terhadap aktivitas kehidupan manusia sehari-hari. Orang yang memiliki kemampuan penglihatan jelas, dapat memperoleh informasi lebih banyak dibanding mereka yang mengalami hambatan dalam penglihatan. Keterbatasan fisik yang berhubungan dengan penglihatan dapat juga disebut dengan penyandang tunanetra. Anak yang menyandang cacat fisik dan mental diberikan kesempatan yang sama untuk memperoleh pendidikan yang biasa dan luar biasa. Ada banyak tempat atau yayasan yang membantu para penyandang tunanetra, salah satu yayasan yang menampung para penyandang difabel adalah Yaketunis (Yayasan Kesejahteraan Tunanetra Islam).

Yaketunis merupakan yayasan yang di dalamnya terdapat sekolah yang terdiri dari beberapa kelas. Ruang kelas ini mempunyai beberapa meja dan kursi yang digunakan untuk menunjang anak belajar setiap hari. Meja merupakan salah satu fasilitas sekolah berupa permukaan datar yang disokong oleh beberapa kaki dan ada yang memiliki laci. Sedangkan kursi adalah sebuah fasilitas sekolah yang digunakan untuk duduk serta memiliki beberapa kaki untuk mendukung berat tubuh pengguna dan ada yang memiliki sandaran kursi. Meja dan kursi merupakan sarana pendukung yang menunjang aktivitas belajar mengajar di sekolah.

Anak menggunakan meja dan kursi sekolah selama kurang lebih enam jam lamanya setiap hari ketika proses belajar-mengajar berlangsung. Jika sikap duduk anak tunanetra tidak benar seperti membungkuk ke depan, maka perkembangan tulang belakang anak akan terganggu. Maka, meja dan kursi sekolah harus diredesain sesuai dengan ukuran tubuh anak tunanetra atau ergonomis. Meja dan kursi sekolah yang ergonomis akan membuat anak tunanetra merasa aman, nyaman, dan sehat sehingga tidak menimbulkan keluhan muskuloskeletal. Sebaliknya, jika meja dan kursi tidak ergonomis akan menimbulkan berbagai dampak negatif baik dalam jangka panjang maupun jangka pendek seperti pemakaiannya akan cepat merasakan lelah, nyeri, dan mengalami keluhan muskuloskeletal.

Berdasarkan penelitian yang dilakukan oleh Chiu et al. (2012) di Taiwan, ketidakergonomisan meja dan kursi pada sekolah tingkat dasar mengakibatkan sakit pada tulang belakang dikarenakan postur tubuh bekerja secara tidak alami dan mengganggu pertumbuhan tulang pada anak. Penelitian lainnya dilakukan oleh Sutafa et al. (2012) di Bali yang menyatakan bahwa anak mengalami keluhan muskuloskeletal utamanya pada leher, bahu, tulang belakang, pinggang, pantat, siku, paha, dan pangkal kaki serta mampu mengurangi konsentrasi anak selama belajar yang diakibatkan oleh ketidakergonomisan meja dan kursi sekolah.

Dari penelitian di atas dapat diketahui bahwa telah banyak penelitian mengenai meja dan kursi pada sekolah-sekolah termasuk di Indonesia. Tetapi, aplikasi hasil penelitian masih jarang direalisasikan sehingga meja dan kursi sekolah dalam negeri cenderung hanya memperhatikan aspek fungsional semata, tanpa memperhatikan aspek ergonomis maupun estetis. Sama halnya dengan penelitian mengenai meja dan kursi sekolah dilakukan di Yaketunis. 
Penelitian pendahuluan dilakukan terhadap siswa kelas satu dan kelas lima dengan checklist penelitian dan Standard Nordict Questionnaire (SNQ). Hasil checklist penelitian pada siswa di Yaketunis diperoleh bahwa ketidaksesuaian dimensi meja dan kursi ini cenderung mengakibatkan ketidaknyamanan dalam belajar akibat postur tubuh siswa berada pada posisi tubuh yang tidak normal. Dalam hal ini posisi tubuh siswa membungkuk sehingga siswa sering mengalami keluhan muskuloskeletal yang diukur dengan SNQ dengan kategori agak sakit pada leher bagian atas, tangan kanan, lutut kanan dan kaki kanan. Keluhan sakit sering dialami siswa pada bagian tubuh punggung, pinggang, leher bagian atas, siku kiri dan lutut kanan. Hal itu mengakibatkan ketidaknyamanan siswa selama belajar yang ditandai dengan kaki siswa yang menggantung dan tulang belakang siswa yang tidak ditopang oleh sandaran kursi. Kemudian hasil dari data yang diperoleh, dirancang dengan menggunkan metode design thinking yang mengedepankan ide-ide dari sang perancang. Oleh karena itu, penelitian ini penting dilakukan untuk meminimalisasi ketidaksesuaian meja dan kursi sekolah terhadap siswa serta untuk mendapatkan hasil redesain meja dan kursi yang ergonomis.

\section{Metode Perancangan}

Penelitian dilakukan di Yaketunis, Yogyakarta dengan subjek penelitian adalah siswa kelas satu dan kelas lima yang berumur 7 tahun sampai 12 tahun yang berjumlah 28 anak. Metode yang digunakan untuk perancangan bentuk redisain produk adalah dengan mengunakan metode design thinking metode ini merupakan sebuah metode berpikir yang mengadopsi cara seseorang memikirkan dan mengerjakan proses kreatifnya dalam mengerjakan sesuatu. Perbedaan yang menonjol dari proses berpikirnya seorang perancang dibanding proses berpikir pada umumnya adalah bahwa dalam proses kreatifnya, perancang tidak memulai pemikirannya dengan pendekatan permasalahannya apa (problem-centered approach) melainkan memulai proses kreatifnya melalui empati terhadap kebutuhan manusia. Tahap awal penelitian dilakukan dengan studi pendahuluan berupa penyebaran checklist penelitian dan kuesioner SNQ kepada siswa untuk mengetahui persentase ketidaksesuaian meja dan kursi sekolah dengan dimensi tubuh siswa serta adanya keluhan muskuloskeletal yang dialami siswa. Kemudian, peneliti mengamati dan menganalisis postur tubuh siswa dengan metode RULA (Rapid Upper Limb Assessment). Selanjutnya, peneliti mengukur antropometri tubuh siswa dan redesain meja dan kursi siswa secara ergonomis berdasarkan langkah perancangan menurut Pahl dan Beitz. Metode Pahl dan Beitz terdiri dari perencanaan dan penjelasan tugas, perancangan konsep produk, perancangan bentuk produk dan perancangan detail. Instrumen yang digunakan adalah kamera, kursi antropometri, timbangan, goniometer, heightometer dan meteran.

Metode Glinski, 2012, mengkolaborasikan proses-proses sistematis yang berpusat pada manusia sebagai penggunanya melalui proses terencana sehingga menghasilkan perubahan perilaku dan kondisi yang sesuai harapan. 


\section{Hasil dan Pembahasan}

Hasil data checklist penelitian dan Standard Nordic Qustionaire (SNQ) penelitian diisi oleh siswa untuk mengetahui ketidaksesuaian dimensi meja dan kursi terhadap siswa. Penilaian untuk checklist penelitian ini diberikan dengan bobot persentase (\%). Rekapitulasi check penelitian dapat dilihat pada Tabel 1.

Tabel 1. Rekapitulasi Checklist Penelitian (\%)

\begin{tabular}{|c|c|c|c|}
\hline No & Pernyataan & Kelas satu & Kelas lima \\
\hline 1 & $\begin{array}{l}\text { Tinggi meja tidak sesuai dengan tinggi siku } \\
\text { dalam posisi duduk. }\end{array}$ & 100 & 100 \\
\hline 2 & $\begin{array}{l}\text { Lebar meja tidak sesuai dengan panjang } \\
\text { rentang tangan ke depan. }\end{array}$ & 71,19 & 100 \\
\hline 3 & $\begin{array}{l}\text { Tinggi meja dari bawah meja tidak sesuai } \\
\text { dengan tebal paha. }\end{array}$ & 100 & 98,73 \\
\hline 4 & $\begin{array}{l}\text { Tinggi kursi tidak sesuai dengan tinggi } \\
\text { popliteal. }\end{array}$ & 100 & \\
\hline 5 & Lebar kursi tidak sesuai dengan lebar pinggul. & 100 & 97,47 \\
\hline 6 & $\begin{array}{l}\text { Panjang kursi tidak sesuai dengan panjang } \\
\text { popliteal. }\end{array}$ & 100 & 89,87 \\
\hline 7 & $\begin{array}{l}\text { Tinggi sandaran punggung kursi tidak sesuai } \\
\text { dengan tinggi bahu dalam posisi duduk. }\end{array}$ & 77,97 & 96,20 \\
\hline 8 & $\begin{array}{l}\text { Lebar sandaran punggung kursi tidak sesuai } \\
\text { dengan lebar sisi bahu. }\end{array}$ & 100 & 91,14 \\
\hline
\end{tabular}

Berdasarkan tabel 1 dapat diketahui bahwa persentase ketidaksesuaian dimensi meja dan kursi sekolah dengan dimensi tubuh siswa tergolong tinggi yaitu berada di atas $70 \%$ untuk kelas satu dan kelas lima.

Adapun penjelasan kategori keluhan yang dirasakan siswa saat belajar adalah sebagai berikut:

a. Rasa agak sakit, hal ini apabila siswa hanya merasakan rasa nyeri sesekali saja ataupun kesemutan.

b. Rasa sakit, hal ini apabila siswa sering merasakan rasa nyeri pada bagian tubuh ataupun pegal. 
Adapun rekapitulasi jenis keluhan dapat dilihat pada Tabel 2.

\begin{tabular}{|r|l|c|c|}
\hline \multicolumn{1}{|r|}{ No } & \multicolumn{1}{|c|}{ Jenis Keluhan } & $\begin{array}{c}\text { Keluhan Agak } \\
\text { Sakit }(\%)\end{array}$ & $\begin{array}{c}\text { Keluhan Sakit } \\
(\%)\end{array}$ \\
\hline 1 & Sakit kaku di leher bagian atas & 29,0 & 5,8 \\
\hline 3 & Sakit di bahu kiri & 21,7 & 3,6 \\
\hline 4 & Sakit di bahu kanan & 15,6 & 2,2 \\
\hline 6 & Sakit lengan atas & 15,9 & 10,1 \\
\hline 7 & Sakit di punggung & 13,0 & 4,3 \\
\hline 8 & Sakit lengan atas & 21,7 & 8,0 \\
\hline 9 & Sakit di pinggang & 15,6 & 3,6 \\
\hline 10 & Sakit pada bokong & 21,7 & 2,2 \\
\hline 11 & Sakit pada pantat & 15,6 & 3,6 \\
\hline 12 & Sakit pada siku & 15,9 & 2,2 \\
\hline 14 & Sakit pada pergelangan tangan & 13,0 & 10,1 \\
\hline 16 & Sakit pada tangan & 13,8 & 4,3 \\
\hline 17 & Sakit pada paha & 21,7 & 8,0 \\
\hline 18 & Sakit pada lutut & 15,9 & 3,6 \\
\hline 19 & Sakit pada betis & 13,0 & 4,3 \\
\hline 20 & Sakit pada pergelangan kaki & & \\
\hline
\end{tabular}

Berdasarkan Tabel 2 dapat diketahui bahwa keluhan muskuloskeletal tertinggi untuk kategori sakit terdapat pada anggota tubuh bagian punggung, pinggang, siku, lutut, paha, kaki, dan leher. Hal ini dikarenakan posisi tubuh siswa membungkuk dan bahu siswa naik pada saat menulis karena meja terlalu tinggi dengan siswa.

\section{Data Postur Tubuh Siswa Postur}

Tubuh siswa merupakan posisi tubuh siswa saat menggunakan meja dan kursi sekolah. Tugas dasar siswa adalah menulis. Faktor kenyamanan pada saat menulis yaitu meja yang digunakan sesuai dengan tinggi siku pengguna. Sedangkan faktor kenyamanan pada saat duduk yaitu jika paha pengguna terbentuk horizontal dan betis pengguna terbentuk vertikal dengan kaki serta kaki harus menyentuh lantai. Oleh karena itu, dilakukan pengamatan terhadap siswa yang sering merasakan keluhan sakit dan keluhan sangat sakit pada Gambar 1 . 

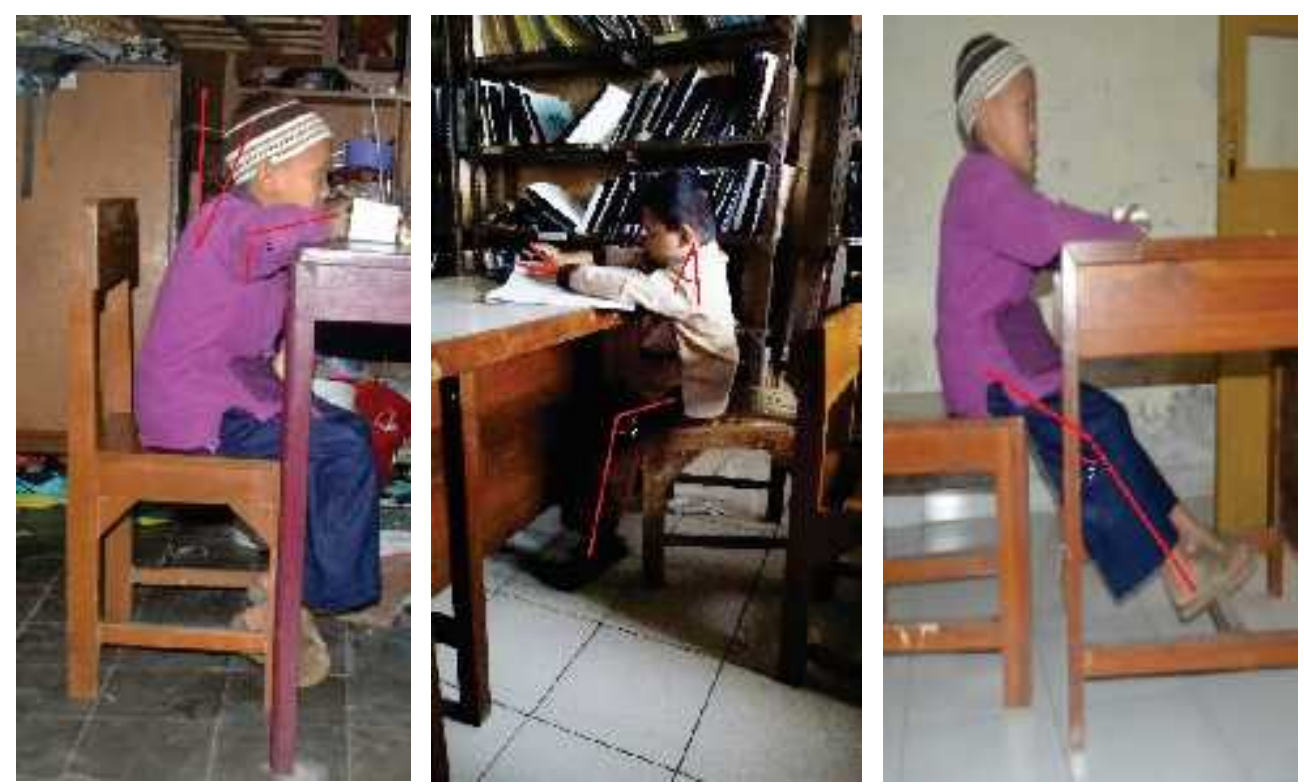

Gambar 1. Postur Tubuh Siswa Menggunakan Meja dan Kursi

Adapun keterangan dari Gambar 1 di atas yaitu:

a. Lengan atas membentuk sudut $460^{\circ}$ dan bahu naik.

b. Lengan bawah membentuk sudut $980^{\circ}$ dan lengan bekerja melewati garis tubuh.

c. Pergelangan tangan membentuk sudut $140^{\circ}$.

d. Putaran pergelangan tangan berada pada posisi tengah putaran tubuh.

e. Lutut kaki membentur pembatas meja.

f. Leher membentuk sudut $160^{\circ}$ dan bengkok.

g. Batang tubuh membentuk sudut $260^{\circ}$ dan bengkok.

h. Kaki siswa tidak seimbang.

\section{Redesain Meja dan Kursi Sekolah Berdasarkan Langkah-langkah Perancangan menurut Pahl dan Beitz}

Adapun langkah-langkah perancangan menurut Pahl dan Beitz adalah:

1. Perencanaan dan penjelasan tugas

Dalam hal ini, perancang menyusun spesifikasi produk yang mempunyai fungsi khusus dan karakteristik tertentu yang memenuhi kebutuhan. Caranya, informasi dikumpulkan sebanyak mungkin tentang kebutuhan (demand) yang harus dipenuhi oleh produk dan keinginan (wishes) dari pengguna. Informasi tersebut disusun dalam bentuk daftar spesifikasi produk. Selanjutnya, analisa dilakukan untuk memperoleh gambaran umum dari spesifikasi yang diberikan. Adapun tugas utama perancangan pada langkah perencanaan dan penjelasan tugas adalah redesain meja dan kursi siswa sekolah dasar yang ergonomis.

2. Perancangan konsep produk

Dalam hal ini dilakukan pengembangan konsep produk yang memenuhi persyaratan-persyaratan dalam spesifikasi produk. Adapun kriteria berdasarkan pada:

a. Memenuhi fungsi secara keseluruhan.

b. Dapat memenuhi yang disyaratkan. 
c. Mudah dibuat.

d. Keamanan terjamin.

e. Lebih disukai perancang.

f. Informasi memadai.

g. Stabilitas produk.

Berdasarkan kriteria tersebut konsep yang memenuhi semua kriteria adalah gabungan konsep one piece dan adjustable.

3. Perancangan bentuk produk

Pada fase perancangan bentuk, konsep produk menggunakan metode design thinking yang lebih mengutamakan ide-ide dari permasalahan yang terdapat pada keergonomian meja dan kursi sehingga dapat mewujudkan bentuk yang sesuai dengan kebutuhan si pengguna. Dalam proses perencanaan, pengembangan ide-ide sangat diperlukan untuk memperbaiki dan mengembangkan desain aktual meja dan kursi di Yaketunis yang sudah ada terlebih dahulu.

\section{Perancangan detail}

Pada fase ini komponen produk, bentuk, dan dimensi dari setiap komponen produk ditetapkan. Adapun variabel redesain meja dan kursi sekolah secara ergonomis berdasarkan dimensi antropometri yang digunakan perancang adalah:

\section{a. Tinggi meja}

Tinggi meja $=$ tinggi popliteal + tinggi siku duduk

Data antropometri yang digunakan adalah data siswa dengan persentil 5 th dan persentil 95 th yaitu:

$$
\begin{aligned}
& \text { tinggi minimum meja }=30,2+11,2=41,4 \mathrm{~cm} \\
& \text { tinggi maksimum meja }=40,6+18,3=58,9 \mathrm{~cm}
\end{aligned}
$$

b. Lebar meja

Lebar meja ditentukan oleh panjang rentang tangan ke depan. Dalam hal ini ukuran lebar meja ditentukan oleh data rata-rata antropometri siswa yaitu $56,3 \mathrm{~cm}$.

c. Tinggi meja dari bawah meja

Tinggi meja dari bawah meja = tinggi popliteal + tebal paha

Data diambil dari data antropometri siswa persentil 5 th yaitu: tinggi minimum dari bawah meja $=30,2+5,7=35,9 \mathrm{~cm}$. Berdasarkan ukuran tersebut, dilakukan perhitungan untuk menentukan tinggi laci yang ditentukan dengan ukuran minimum tinggi meja dan ukuran minimum tinggi meja dari bawah meja yaitu: tinggi laci $=41,4-35,9=5,5 \mathrm{~cm}$.

\section{d. Tinggi kursi}

Tinggi kursi = tinggi popliteal siswa

Data diambil dari data antropometri siswa persentil 5 th dan persentil 95 th yaitu:

1) Tinggi minimum kursi $=30,2 \mathrm{~cm}$

2) Tinggi maksimum kursi $=40,6 \mathrm{~cm}$

e. Lebar kursi

Lebar kursi = lebar pinggul siswa

Data diambil dari data siswa dengan persentil 95 th yaitu $27,3 \mathrm{~cm}$.

f. Panjang kursi

Panjang kursi $=$ panjang popliteal siswa

Data diambil dari data siswa dengan persentil 95 th yaitu $39,2 \mathrm{~cm}$. 


\section{g. Tinggi sandaran punggung kursi}

Tinggi sandaran punggung $=$ tinggi bahu duduk

Data diambil dari data rata-rata antropometri siswa yaitu $=43,5 \mathrm{~cm}$.

h. Lebar sandaran punggung kursi

Lebar sandaran punggung kursi= lebar sisi bahu

Data diambil dari data siswa dengan persentil 95 th yaitu $32,6 \mathrm{~cm}$.

\section{Hasil Redesain Meja dan Kursi Hasil}

Adapun gambar detail meja dan kursi hasil redesain beserta spesifikasinya dapat dilihat pada gambar 2 dan gambar 3.

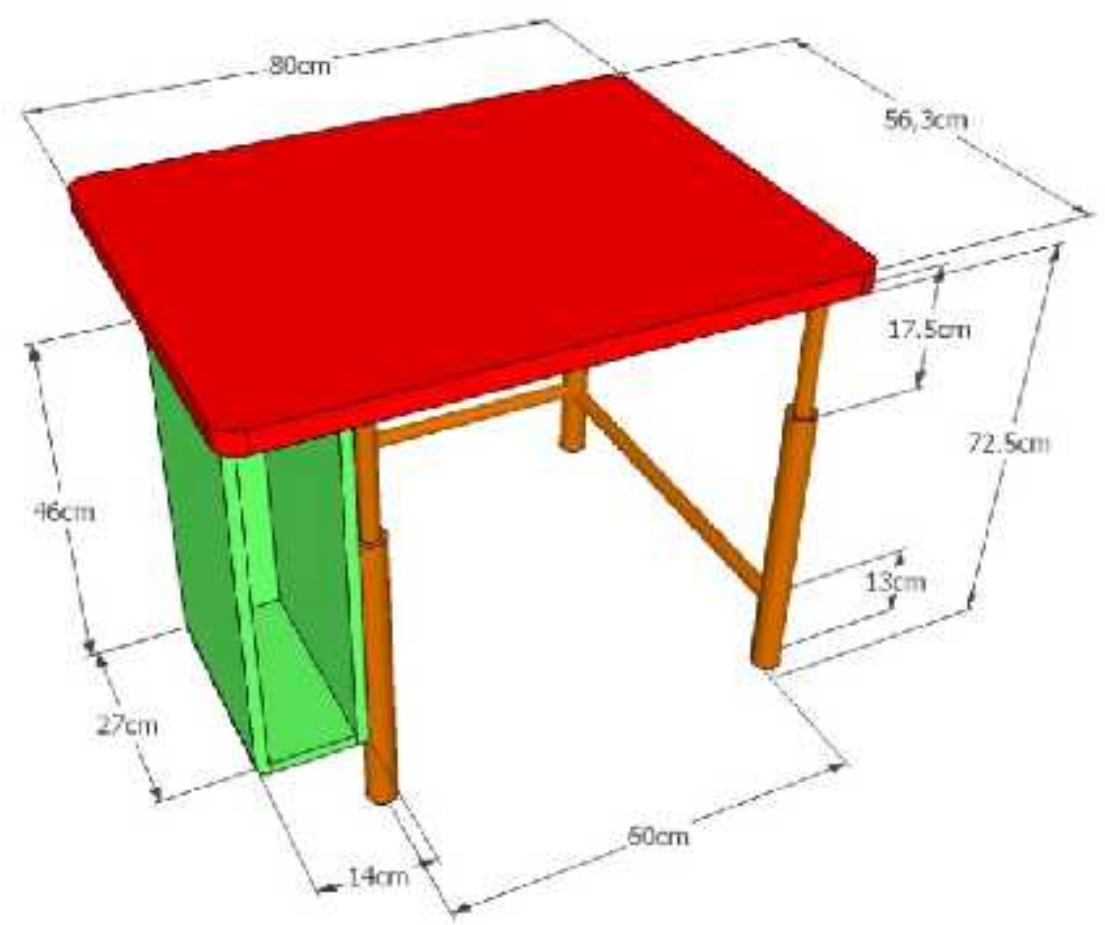

Gambar 2. Meja Hasil Redesain (cm) 


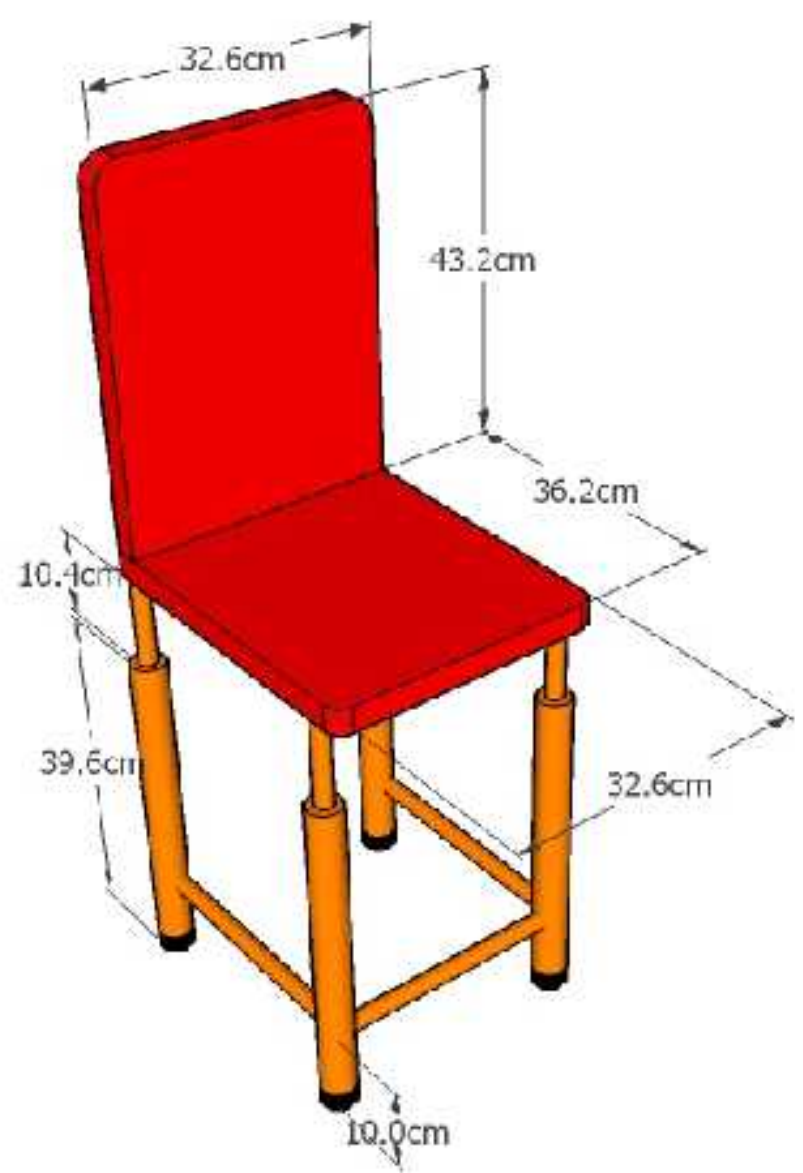

Gambar 3. Kursi Hasil Redesain (cm)

Gambar 2 merupakan gambar detail hasil redesain meja dan Gambar 3 merupakan gambar detail hasil redesain kursi. Dari gambar di atas, pada bagian bawah meja dan kursi terdapat dua handle untuk mengatur tinggi meja dan tinggi kursi. Sedangkan tinggi pijakan kaki meja dan tinggi pijakan kaki kursi disesuaikan dengan peraturan yang ditetapkan oleh Menteri Pendidikan dan Kebudayaan Republik Indonesia Nomor 56 Tahun 2011 tentang petunjuk teknis penggunaaan dana alokasi khusus bidang pendidikan tahun anggaran 2012 untuk sekolah dasar atau sekolah dasar luar biasa yang berkaitan dengan standar dan spesifikasi teknik perabot ruang kelas kategori tinggi pijakan kaki meja siswa tunggal dan tinggi pijakan kaki kursi siswa tunggal yaitu $13 \mathrm{~cm}$ dan $10 \mathrm{~cm}$.

Tempat penyimpanan tas atau buku terletak pada bagian samping dari meja, ini dikarenakan agar anak lebih mudah untuk mengambil suatu barang dan lutut si pengguna tidak terbentur oleh tempat penyimpanan tersebut. Desain ini juga diperkuat oleh Neufert (1989) yang mengatakan, sebaiknya tidak dipasang laci penyimpanan di bawah meja kecuali di samping tempat kaki atau dengan jalan memperlebar ukuran daun meja.

Desain bagian sudut pada sisi meja dibuat tumpul ini disebabkan agar jika anak tidak sengaja membenturkan tangannya ke sisi sudut meja, tangan mereka tidak terluka ataupun tergores, pendapat ini juga diperkuat dari Departemen Pekerjaan Umum (2006) 
bentuk perabot bagi difabel harus dirancang berdasarkan kebutuhan orang untuk bergerak aman, mudah, nyaman, dan tanpa hambatan.

Sedangkan ukuran handle yang digunakan berdiameter $3 \mathrm{~cm}$ dengan panjang 10 $\mathrm{cm}$. Hal ini terkait dengan syarat yang diajukan Dul and Weerdmeester (1993) pada karya tulis Arimbawa yang berjudul "Aspek Metodologi dalam Penelitian Ergonomi untuk Mencapai Kenyamanan dalam Pemakaiannya".

Berdasarkan pengukuran yang telah dilakukan terhadap dimensi meja dan kursi sekolah, terdapat beberapa ketidaksesuaian dimensi dari kedua jenis meja dan kursi dengan data antropometri tubuh siswa. Sehingga perlu dilakukan perbaikan untuk mendapatkan desain meja dan kursi yang ergonomis. Oleh karena itu dilakukan pengukuran antropometri terhadap siswa. Adapun dimensi kedua jenis meja dan kursi dengan dimensi hasil redesain dapat dilihat pada Tabel 3.

\begin{tabular}{|r|l|c|c|c|c|}
\hline \multirow{2}{*}{ No } & \multirow{2}{*}{ Keterangan } & \multirow{2}{*}{ Ukuran1 } & \multirow{2}{*}{ Ukuran 2 } & \multicolumn{2}{|c|}{ Hasil redesain } \\
\cline { 4 - 6 } & & 73 & 75 & 42,6 & 60,2 \\
\hline 1 & Tinggi meja & 60 & 80 & 56,3 & 56,3 \\
\hline 2 & Lebar meja & 55 & 50 & 60 & 60 \\
\hline 3 & Panjang meja & 41 & 45 & 36,8 & 54,4 \\
\hline 4 & Tinggi kursi lebar kursi & 41 & 43 & 31,7 & 41,7 \\
\hline 5 & Lebar kursi & 42 & 40 & 39,5 & 39,5 \\
\hline 6 & Panjang kursi & 37 & 39 & 43,2 & 43,2 \\
\hline 7 & Tinggi sandaran punggung & 37 & 45 & 34,7 & 34,7 \\
\hline 8 & Lebar sandaran punggung & 43 & \multicolumn{2}{|c}{} \\
\hline
\end{tabular}

Tabel 3. Perbandingan Dimensi Meja dan Kursi

Dari Tabel 3 dapat diketahui bahwa terdapat beberapa perbedaan yang signifikan antara dimensi meja dan kursi aktual dengan meja dan kursi hasil redesain. Hasil redesain meja dan kursi yang dilakukan peneliti adalah meja dan kursi dengan konsep adjustable yang dikombinasi dengan konsep one piece. Dalam hal ini tinggi meja dan tinggi kursi bisa dinaik-turunkan sesuai dimensi tubuh pengguna berdasarkan ukuran maksimum (maks) dan ukuran minimum (min) meja dan kursi hasil redesain. Hal ini dikarenakan terlalu besarnya perbedaan dimensi tubuh siswa satu dengan yang lainnya.

\section{Analisis Postur Tubuh Siswa}

Ketidaksesuaian dimensi meja dan kursi sekolah dengan penggunanya mengakibatkan postur tubuh yang salah. Analisis postur tubuh dilakukan untuk mengetahui kategori level resiko dan tindakan yang harus dilakukan. Dalam hal ini dibuat model manusia sesuai dengan data antropometri yang dikumpulkan. Kemudian postur tubuh siswa dianalisis dengan metode penilaian postur tubuh dengan menggunakan meja dan kursi hasil redesain pada saat menulis dapat dilihat pada Gambar 4. 


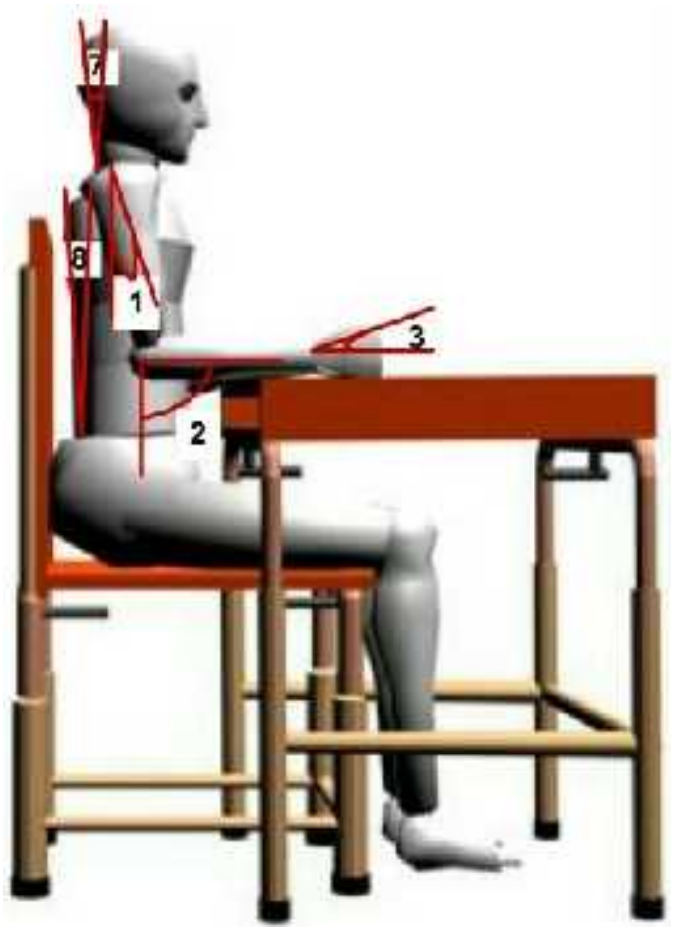

Gambar 4. Postur Tubuh Siswa Menggunakan Meja dan Kursi Hasil Redesain

Adapun keterangan dari Gambar 4 di atas yaitu:

1. Lengan atas membentuk sudut $180^{\circ}$.

2. Lengan bawah membentuk sudut $90^{\circ}$.

3. Pergelangan tangan membentuk sudut $100^{\circ}$.

4. Putaran pergelangan tangan berada pada posisi tengah putaran tubuh.

5. Aktivitas pengulangan.

6. Beban $<2 \mathrm{~kg}$.

7. Leher membentuk sudut $80^{\circ}$.

8. Batang tubuh membentuk sudut $40^{\circ}$.

9. Kaki siswa seimbang.

Berdasarkan Gambar 4 dapat diketahui bahwa penilaian postur tubuh siswa dengan memiliki level resiko dengan kategori resiko kecil dan kategori tindakan yaitu diperlukan tindakan beberapa waktu ke depan. Pada saat menulis menggunakan meja dan kursi hasil redesain, posisi tubuh siswa tidak membungkuk dan bahu siswa tidak terangkat serta kaki siswa menyentuh lantai. Hal ini dikarenakan meja dan kursi hasil redesain sesuai dengan dimensi tubuh siswa. 


\section{Kesimpulan}

Berdasarkan hasil penelitian yang telah dilakukan dapat diketahui dimensi meja dan kursi sekolah berpengaruh pada postur tubuh anak. Apabila dimensi meja dan kursi sekolah yang digunakan sesuai dengan anak, maka postur tubuh anak tidak akan membungkuk dan anak nyaman menggunakannya. Sebaliknya, jika dimensi meja dan kursi sekolah tidak sesuai dengan anak maka anak akan mengalami keluhan muskuloskeletal. Oleh karena itu, kesesuaian dimensi meja dan kursi sekolah dengan dimensi tubuh siswa akan membuat kondisi belajar siswa yag efektif, nyaman, aman, sehat dan efisien.

\section{Kepustakaan}

Ahmad Maulana. Dkk. 2003. Kamus Ilmiah Populer. Yogyakarta: Absolut.

Ching, D. K.. 1987. Interior Design Illustrated. New York: Van Nostrand Reinhold Company.

Departemen Pekerjaan Umum. 1998. Keputusan Menteri Pekerjaan Umum RI No.468/KPPS/1998: Persyaratan Teknis Aksesibilitas pada Bangunan Pekerjaan Umum dan Lingkungan, Jakarta.

Dr. Suma'mur P.K, Msc. 1989. Ergonomi untuk Produktivitas Kerja. Jakarta: CV. Masagung.

.Hadikasma, Apurwanta. 1987. Orientasi dan Mobilitas Tunanetra. Yogyakarta: Pengempangan Perguruan Tinggi IKIP Yogyakarta.

Lydon, W. T. \& Graw, M. 1. Mc. 1973. Pengembangan Konsepsi untuk Anak-anak Buta. Amerika: America Foundation for the Blind, Inc.

Panero. J. \& Zelnik, Martin. 1979. Human Dimension and Interior Space, Whitney Library of Design. New York: The Architectureral Pres Ltd.

Weissmann, G. 1981. Modeling Enviromental Behaviour Systems. Journal of ManEnviroment Relations.

Woodson, Wesley E. 1981. Human Factors Design Handbook. New York: McGraw-Hill Book Company. 